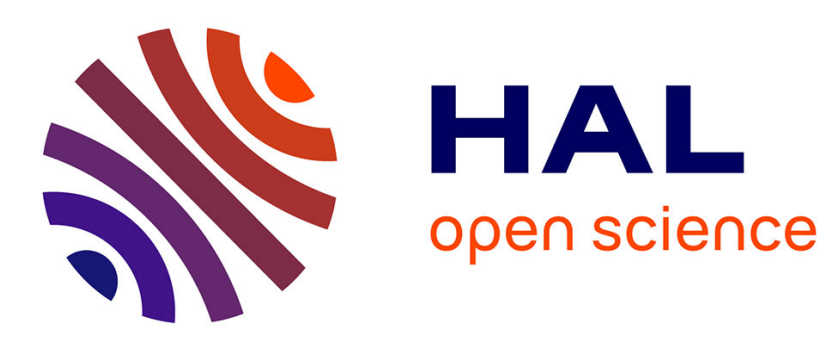

\title{
Colonization of heavy metal-polluted soils by Collembola: preliminary experiments in compartmented boxes
}

\author{
Matthieu Chauvat, Jean-François Ponge
}

\section{To cite this version:}

Matthieu Chauvat, Jean-François Ponge. Colonization of heavy metal-polluted soils by Collembola: preliminary experiments in compartmented boxes. Applied Soil Ecology, 2002, 21 (2), pp.91-106. 10.1016/S0929-1393(02)00087-2 . hal-00498579

\section{HAL Id: hal-00498579 \\ https://hal.science/hal-00498579}

Submitted on 7 Jul 2010

HAL is a multi-disciplinary open access archive for the deposit and dissemination of scientific research documents, whether they are published or not. The documents may come from teaching and research institutions in France or abroad, or from public or private research centers.
L'archive ouverte pluridisciplinaire HAL, est destinée au dépôt et à la diffusion de documents scientifiques de niveau recherche, publiés ou non, émanant des établissements d'enseignement et de recherche français ou étrangers, des laboratoires publics ou privés. 


\title{
Colonization of heavy metal polluted soils by Collembola: preliminary experiments in compartmented boxes
}

\author{
Matthieu Chauvat ${ }^{1}$, Jean-François Ponge ${ }^{2}$ \\ Museum National d'Histoire Naturelle, Laboratoire d'Ecologie Générale, 4 avenue du Petit-Château, \\ 91800 Brunoy, France
}

\section{Abstract}

Two-week laboratory experiments were carried out in plastic boxes separated in two connected compartments filled with a neutral soil (mull humus) at pH 7.7 and an acid soil (moder humus) at pH 4.3, containing their original faunas. Migration of Collembola from one compartment to the other was allowed through a perforated wall. The mull was contaminated with three concentrations of lead (as lead acetate) at 50, 6,000 and 60,000 ppm. When combined with moder in the adjacent compartment, 6 times more individuals and 5 times more species were observed in the mull at the highest concentration applied, compared to mull combined with itself. Parisotoma notabilis proved to be highly sensitive to lead, and shifted to the moder compartment even at the lowest concentration. Densities of other mull species such as Pseudosinella alba were affected by medium to high concentrations of lead but these species did not move to the moder soil despite their high motility. Acidophilic species living in moder only, such as Willemia anophthalma, Xenylla tullbergi, Proisotoma minima and Xenylla tullbergi, colonized contaminated mull treatments with densities increasing with lead concentrations but the result of this process was erratic. Folsomia manolachei was present in both humus forms but was much more abundant in the moder. This species colonized mull at medium to high lead concentrations, where it restored totally or partly its original abundance in the uncontaminated mull. These results suggested differences between mull and moder populations of Folsomia manolachei.

\footnotetext{
${ }^{1}$ Present address: Justus Liebig University, Department of Animal Ecology, Heinrich-Buff-Ring 26-32, 35392 Giessen, Germany

${ }^{2}$ Corresponding author. Tel. +33160479213 , Fax +331 60465009, e-mail: jeanfrancois.ponge@wanadoo.fr
} 
Keywords: Collembola, Acidophily, Heavy metals, Migration, Sensitivity.

\section{Introduction}

The sensitivity of Collembola (Hexapoda) to heavy metals has been the subject of recent investigations, pointing on the heritability of resistance in populations submitted to long-term contamination of soils (Posthuma, 1990; Posthuma et al., 1993; Tranvik et al., 1994). Several studies have been carried out on collembolan communities, showing that shifts in species composition occurred under the influence of heavy metal contamination, together with a decrease in biodiversity (Hågvar and Abrahamsen, 1990; Filser and Hölscher, 1997; Bruus Pedersen et al., 1999).

The sensitivity of different species of Collembola to soil acidity has been recognized for a long time (Gisin, 1943; Mertens, 1975; Hågvar and Abrahamsen, 1984; Loranger et al., 2001). Experiments with artificial acid rain have shown that species living only in acid soils such as Willemia anophthalma, Micranurida pygmaea and Mesaphorura yosii were favoured by the application of sulphuric acid. Other species, present in acid soils but more abundant in neutral soils, such as Parisotoma notabilis, were eliminated by the same experimental conditions (Bååth et al., 1980; Hågvar and Kjøndal, 1981; Hågvar, 1984).

The presence of high concentrations of aluminum, iron and other metals in the soil solution when soils are very acid (Bergkvist, 1987; Lundström et al., 2000), and the increased ecological effects of heavy metals at low pH (Crommentuijn et al., 1997), led us to postulate that tolerance to heavy metals and tolerance to acidity could be ecologically related. Specifically, animals living in acid soils, either at the species or the sub-species level, could be more tolerant to heavy metals than animals commonly living in neutral or weakly acidic soils. The threshold of $\mathrm{pH} 5$, below which changes in collembolan species composition have been recorded (Ponge, 1983; Ponge, 1993; Ponge, 2000a), is also a threshold under which aluminum passes into the soil solution as a metal cation and may exert severe toxicity, mostly by negatively interacting with phosphorus metabolism (Clarkson, 1969; James and Riha, 1984; Berggren et al., 1990). Given a common detoxication strategy in Collembola and other Hexapoda, i.e. by periodically renewing the midgut epithelium (Joosse and Buker, 1979; Hopkin, 
1 1995), it can be hypothesized that species living in naturally acidic soils (and thus thought tolerant or resistant to free metallic forms) are able to colonize neutral or weakly acidic soils contaminated with heavy metals as a consequence of human activities such as mining, agriculture and industry.

It is intended to test this hypothesis in the long-term by inoculating acid humus profiles, with their complete acido-tolerant collembolan communities, into metal-contaminated sites. Prior to undertaking field experiments, a preliminary study was conducted in order to verify whether Collembola living in acid soils are able to leave their original habitat to colonize a neutral soil polluted with heavy metals.

\section{Materials and Methods} move between compartments, one filled with an acid soil (moder humus), and another filled with a neutral soil (mull humus) treated with lead acetate at different concentrations. Two soils were chosen, a Dysmoder, characterized by the accumulation of organic matter in the form of small enchytraeid faeces, and an Eumull, characterized by a rapid mixing of organic matter to mineral matter through earthworm activity (Brêthes et al., 1995; Ponge, 1999). These soils contain very different collembolan communities (Ponge, 1993; Chagnon et al., 2000). Lead acetate was chosen as the metal salt in order to avoid possible toxic effects of the anion. Given the rapid disappearance of acetate in a biologically active soil (Verschueren, 2001), most lead becomes rapidly complexed by soil organic matter (Sarret et al., 1997; Balabane et al., 1999).

Topsoil horizons, with their complete original fauna, were collected in May 2000. The Eumull material $(\mathrm{pH} 7.7)$ was collected in a rendzina soil in the park adjacent to the laboratory (Brunoy, 20km south of Paris) under oak (Quercus robur L.) and hornbeam (Carpinus betulus L.), with a ground flora of ivy (Hedera helix L.) and dog's mercury (Mercurialis perennis L.). The sparse litter horizon was discarded, together with aerial parts of ground vegetation, and the top $10 \mathrm{~cm}$ of the A horizon were collected over a square meter area. The Dysmoder material ( $\mathrm{pH} 4.3)$ was collected over the same area in a pine stand (Pinus sylvestris L.) located in the Senart forest near the laboratory. The ground 
cover was mainly bramble (Rubus fruticosus L.) and bracken [Pteridium aquilinum (L.) Kuhn]. The superficial litter (OL horizon) was discarded, and only the OF horizon (fragmented litter) and the thick $\mathrm{OH}$ horizon (humified litter, $10 \mathrm{~cm}$ thick) were collected. In both cases the soil was thoroughly crumbled by hand, most woody subterranean parts of vegetation, earthworms and stones being discarded.

Experiments were carried out in polystyrene boxes $(175 \times 115 \mathrm{~mm}, 65 \mathrm{~mm}$ deep) which were divided in two compartments by a $2 \mathrm{~mm}$ thick millboard $\left(\right.$ Isore $\left.{ }^{\circledR}\right)$ division, pierced with $4 \mathrm{~mm}$ diameter holes at a rate of 30 holes per wall. The division allowed passage by fauna but prevented physical contact between the two soils. Eumull was treated with lead acetate/deionized water solutions at three dilution rates, giving rise to three concentrations in the soil at $50,6,000$ and $60,000 \mathrm{ppm}$, referred to as low, medium and high concentration, respectively. These concentrations were chosen on the basis of preliminary assays. Control boxes (Eumull or Dysmoder) received deionized water only. Different combinations were established with five replicates each:

E0/E0 Eumull versus Eumull, without any addition of lead in the two compartments

E1/E1 Eumull versus Eumull, with lead at $50 \mathrm{ppm}$ in the two compartments

E2/E2 Eumull versus Eumull, with lead at 6,000 ppm in the two compartments

E3/E3 Eumull versus Eumull, with lead at $60,000 \mathrm{ppm}$ in the two compartments

E0/E1 Eumull versus Eumull, with lead at $50 \mathrm{ppm}$ in only one compartment $(\mathrm{E} 0 / \mathrm{E} 1=$ unpolluted Eumull compartment, E1/E0 = polluted Eumull compartment)

E0/E2 Eumull versus Eumull, with lead at $6,000 \mathrm{ppm}$ in only one compartment (E0/E2 = unpolluted Eumull compartment, E2/E0 = polluted Eumull compartment)

E0/E3 Eumull versus Eumull, with lead at $60,000 \mathrm{ppm}$ in only one compartment (E0/E3 = unpolluted Eumull compartment, E3/E0 = polluted Eumull compartment)

E0/D Eumull versus Dysmoder, without any addition of lead acetate in the Eumull $(E 0 / D=$ Eumull compartment, D/E0 = Dysmoder compartment)

E1/D Eumull versus Dysmoder, with lead at $50 \mathrm{ppm}$ in the Eumull $(\mathrm{E} 1 / \mathrm{D}=$ Eumull compartment, $\mathrm{D} / \mathrm{E} 1$ = Dysmoder compartment)

E2/D Eumull versus Dysmoder, with lead at $6,000 \mathrm{ppm}$ in the Eumull $(E 2 / \mathrm{D}=$ Eumull compartment, $\mathrm{D} / \mathrm{E} 2$ = Dysmoder compartment) 
1

$3 \mathrm{D} / \mathrm{D}$ compartment, $\mathrm{D} / \mathrm{E} 3$ = Dysmoder compartment) Dysmoder versus Dysmoder

The experimental boxes were incubated in the laboratory at $15^{\circ} \mathrm{C}$ in darkness during two weeks. At the end of the incubation period arthropods were extracted by the dry-funnel method. The identification of Collembola was done to the species level under a light microscope at $400 \mathrm{x}$ magnification. After extraction of the microarthropods, the water $\mathrm{pH}$ of the dried soil was measured electrometrically in a 1:3 (w:w) soil:water slurry.

Data $(\mathrm{pH}$ values, abundance of species or groups of species, number of species) were analysed by one-way ANOVA, using boxes as replicates. For treatments where both compartments were filled with the same soil (E0/E0, E1/E1, E2/E2, E3/E3, D/D), average values between paired compartments were used for comparisons with other treatments. When necessary data were logtransformed in order to ensure additivity of variances. Comparisons among means following ANOVA were achieved a posteriori by the SNK procedure (Glantz, 1997). When homogeneity of variances could not be achieved through log-transformation of the data, non-parametric Mann-Whitney rank tests were performed in place of ANOVA (Glantz, 1997).

\section{Results}

\subsection{Comparison between Eumull and Dysmoder populations}

A total of 37 collembolan species were found over the whole set of samples (Table 1). Among these, 17 most frequent species were selected for further analyses (Table 2).

Total abundance of Collembola and species composition of Eumull and Dysmoder soils used for the experiment differed to a great extent, as well as $\mathrm{pH}$ values (Table 2). At the end of the experiment Collembola were twice more abundant in Dysmoder compared to Eumull (Table 2, Fig. 1, compare $E 0 / E 0$ to $D / D$ ), and the number of species was significantly higher (Fig. 2). Some species 
were common to both soils, viz. Dicyrtoma fusca, Folsomia manolachei, Friesea truncata, Isotomiella minor, Lepidocyrtus lanuginosus, Megalothorax minimus, Paratullbergia callipygos and Sphaeridia pumilis. These species were called ubiquitous species. Nevertheless, among this group, some species were much more abundant in one or other of the soils. For instance Folsomia manolachei was 6 times more abundant in Dysmoder than in Eumull (Fig. 3), while Isotomiella minor was twice more abundant in Eumull than in Dysmoder (Table 1). Among species living only in Eumull, called Eumull species, the most frequent ones were Heteromurus nitidus, Parisotoma notabilis and Pseudosinella alba. The most frequent species living only in Dysmoder, called Dysmoder species, were Micranurida pygmaea, Proisotoma minima, Pseudosinella mauli, Sminthurinus signatus, Willemia anophthalma and Xenylla tullbergi. It must be noticed that these features describe the two soil samples at the end of the experimental period. They refer only to one square meter (the area over which the soil was sampled) in each site and they include possible changes due to experimental conditions, thus they do not picture the original population.

The efficiency of the perforated wall for allowing animals to pass from a compartment to another can be assessed by observing that Parisotoma notabilis, absent from the Dysmoder soil used for the experiment, was retrieved in this soil when paired to Eumull at densities equal or even higher than those of Eumull (Fig. 4). Conversely, all Dysmoder species were retrieved in the Eumull compartment when these soils were paired (Fig. 2).

\subsection{Experiments on Eumull alone}

Eumull treatments where both compartments were given the same concentration of lead (E0/E0, E1/E1, E2/E2 and E3/E3) allowed us to quantify, in our experimental conditions, the shortterm impact of lead contamination on collembolan communities. Although soil $\mathrm{pH}$ increased significantly at the highest treatment, the increase was small (from 7.7 to 7.8 ), thus no departure from neutrality was observed in polluted Eumull (Table 3). The total abundance of Collembola, as well as the number of species, decreased only at high concentration (Table 3, Figs. 1 and 2). The general trend of decreased abundance at high concentration only was apparent for the most abundant species, Isotomiella minor, which comprised $57 \%$ of the collembolan population in unpolluted Eumull. 
1 Lepidocyrtus lanuginosus and Heteromurus nitidus exhibited also a decrease in abundance at high concentration only. Nevertheless some species did not follow this general trend. Pseudosinella alba and Sphaeridia pumilis decreased significantly in abundance at medium concentration and totally disappeared at high concentration. Folsomia manolachei (Fig. 3) decreased progressively and significantly in abundance at all three concentrations but never disappeared totally. It was the most abundant species at the end of the experiment at high concentration. Parisotoma notabilis (Fig. 4) decreased only at medium then nearly disappeared at high concentration. Paratullbergia callipygos and Friesea truncata displayed an increase from nil to medium concentration (significant in $P$. callipygos, not significant in $F$. truncata), then disappeared totally at high concentration.

Treatments with Eumull in both compartments but with only one of them polluted with lead allowed to test the hypothesis of a possible refuge effect of unpolluted zones within a polluted site. Increasing the lead concentration in the compartment adjacent to unpolluted Eumull did not affect abundance and species richness of collembolan communities in the unpolluted compartment (Table 4, Figs. 1 and 2). Effects observed in the polluted compartment were similar to those observed when both compartments were equally polluted, i.e. a decrease in abundance of species richness at high concentration only (Table 5, Figs. 1 and 2). At the species level, Folsomia manolachei exhibited a significant decrease in unpolluted Eumull at medium and high concentrations (Table 4, Fig. 3). In the adjacent (polluted) compartment, this species exhibited a strong significant decrease at high concentration only, contrary to the experiment with both compartments equally polluted, where it exhibited a significant decrease as soon as low concentration was applied (Table 3, Fig. 3). No change in $\mathrm{pH}$ was observed in the different treatments (Tables 4 and 5).

\subsection{Experiments on Eumull paired with Dysmoder}

Treatments with Eumull combined with Dysmoder allowed us to test the hypothesis that collembolan species living in acid soils were able to colonize neutral soils polluted with heavy metals. The collembolan community of Eumull exhibited some significant changes when freely communicating with Dysmoder (Table 6, Figs. 1 and 2). In the absence of lead, a significant decrease was observed in the abundance of ubiquitous species, although no significant change occurred in the total 
1 abundance nor in the total number of species (compare E0/E0 with E0/D). At the species level, only

2 Pseudosinella alba was affected by the presence of Dysmoder, its abundance decreasing by a factor

3 of ten (Table 1). Other species did not react significantly.

4

After lead application, the total population of Eumull increased significantly at low and medium concentrations (compare E1/D and E2/D to E0/D). This increase, not observed when Eumull was alone (Table 3, Fig. 1), was due to a strong increase in the abundance of ubiquitous species. At high concentration, the total abundance of Collembola decreased, but was six times higher than when Eumull was alone (Tables 3 and 6, Fig. 1). The improvement due to the presence of Dysmoder was even more pronounced if we take into account the number of species. In the presence of Dysmoder, no decrease in the number of species occurred at the high concentration of lead (Table 6, Fig. 2), although this number was divided by six when Eumull was used alone. The decrease in the abundance of Parisotoma notabilis observed at medium and high concentration when Eumull was used alone (Table 3) was smoothed, although still significant, in the presence of Dysmoder (Table 6, Fig. 4). The same phenomenon was observed, but in a more pronounced way, in Folsomia manolachei, an ubiquitous species. At medium concentration the abundance of this species in Eumull more than doubled under the influence of Dysmoder (Fig. 3, Tables 3 and 6). At high concentration its abundance increased sixfold compared to Eumull alone. The abundance of Isotomiella minor nearly doubled after lead application at low concentration (Table 6), then significantly decreased at high concentration but its abundance was three times that observed in the absence of Dysmoder (Table 3). The Lepidocyrtus lanuginosus population collapsed at high concentration of lead in the absence of Dysmoder, and its abundance remained unchanged below this theshold (Table 3). In the presence of Dysmoder L. lanuginosus exhibited a significant increase in abundance when lead concentration increased, reaching a maximum at medium concentration, then decreased at high concentration (Table 6) but remained 38 times more abundant than in the absence of Dysmoder (Table 3). A small although significant increase (around a tenth unit) in soil pH was observed at high concentration only (Table 6), of the same order as when Eumull was alone (Table 3), and the presence of Dysmoder in a paired compartment did not influence the $\mathrm{pH}$ of Eumull. 
In the absence of lead a few animals belonging to the Dysmoder group of species (Micranurida pygmaea, Pseudosinella mauli, Sminthurinus signatus, Willemia anophthalma, Xenylla tullbergi) were found in the Eumull compartment, and their number increased with lead concentration (Table 6, Fig. 1). Nevertheless this trend was not significant, due to strong departures from a box to another (see standard error values on Table 6).

\section{(}

(1)

8
absence of lead in the Eumull compartment, the number of ubiquitous species decreased significantly in adjacent Dysmoder, as well as the density of the Dysmoder species Willemia anophthalma, and the pH increased slightly but significantly (Table 7, Figs. 1 and 2). When lead was applied to Eumull, the number and the abundance of Eumull species increased with lead concentration in the Dysmoder compartment, their abundance reaching a level nearly twice that of unpolluted Eumull (Table 6). This was mostly due to Parisotoma notabilis, the abundance of which at medium and high concentration of lead reached in Dysmoder a level 2.8 and 2.5 times that of original Eumull (Fig. 4, Table 7). Other species increased their abundance in Dysmoder when lead was applied to Eumull, as for instance the ubiquitous Isotomiella minor, the abundance of which trebled when lead was at medium concentration, and the ubiquitous Lepidocyrtus lanuginosus, the abundance of which near trebled at high concentration (Table 7). The $\mathrm{pH}$ of Dysmoder increased with lead concentration (Table 7).

\section{Discussion}

Despite the absence of significant colonization of the polluted neutral soil by strongly acidophilic species such as Willemia anophthalma, which was yet well-represented in the acid soil used for the experiment, migration movements were clearly demonstrated between the polluted mull and the moder. In the presence of lead, moder acted as a refuge for the isotomid Parisotoma notabilis, coming from the polluted mull. This species is known to live both in acid and neutro-acidocline soils (Ponge 1993), although it proved to be highly sensitive to experimental acidification with sulphuric acid (Bååth et al., 1980; Hågvar and Kjøndal, 1981; Hågvar, 1984), preferred alkalinity in pH-preference tests (Van Straalen and Verhoef, 1997) and was favoured by ash or lime application (Abrahamsen et al., 1980; Hågvar and Abrahamsen, 1980; Vilkamaa and Huhta, 1986). It should be noticed that 
$1 \quad$ P.notabilis, also known for its sensitivity to heavy metals (Tranvik et al., 1993; Bruus Pedersen et al., 2 1999), was strongly depressed in our experiments at medium concentration of lead (6,000 ppm).

The colonization of the polluted mull by the isotomid Folsomia manolachei coming from the moder was clear. This species was present in both humus forms, but it was much more abundant in the moder, which acted as a source for the polluted mull. At medium lead concentration and only in the presence of moder the abundance of this species increased in polluted mull compartments to a level so high that it cannot be explained by another cause than a colonization by specimens coming from the moder. Although the appearance of typical acidophilic species in the polluted mull was not significant, their presence in lead-polluted mull compartments, even at high concentration $(60,000$ ppm), indicated that they were able to colonize soils polluted by heavy metals, but were poorly attracted to them. One possible reason for the lack of a more intense colonization of the polluted mull by the mycetophagous poduromorph Willemia anophthalma (Ponge, 1991; Ponge, 2000b) could be the scarcity of fungi in the mull at neutral $\mathrm{pH}$ used for the experiments, and a subsequent lack of attraction by fungal odour (Bengtsson et al., 1988; Sadaka-Laulan et al., 1998), while fungi where abundant in the acidic moder, as ascertained by visual inspection. Another reason could be the lack of motility of this species, which has particularly short legs compared to that of entomobryomorph (entomobryid and isotomid) species. Isotomid species such as Folsomia manolachei and Parisotoma notabilis have a less specialized feeding habit, their diet being mainly composed of humified organic matter (Ponge, 1991; Ponge, 2000b). They are also much more motile than poduromorphs, due to possessing longer legs and functional furcula (Hopkin, 1997), and these two species are indifferent to soil $\mathrm{pH}$ (Ponge, 1993). These attributes make them better able to move to other places when environmental conditions become unfavourable or when more space or food are available somewhere else. 
If we compare populations of Folsomia manolachei from the acid and neutral soils used for our experiments, it appears that mull specimens were more sensitive to lead application than moder ones. The existence of populations tolerant or intolerant to heavy metals in Folsomia manolachei could be compared to the case of Orchesella cincta where heritability of tolerance to heavy metals has been demonstrated (Posthuma, 1990; Posthuma et al., 1992; Posthuma et al., 1993). In our experiments animals attracted to a soil contaminated by heavy metals did not come from a polluted site but from an acidic coniferous forest soil. The importance of tolerant strains of Folsomia manolachei for the possible reclamation of polluted sites should be stressed, given its wide occurrence in all types of soils (Rusek, 1989; Mateos and Selga, 1991; Ponge, 1993). As in our experiments with lead acetate, this species recolonized soil cores polluted with copper sulphate where it exhibited higher densities than in the unpolluted control (Filser and Hölscher, 1997), and was attracted to copper sulphate solutions in choice experiments (Filser et al., 2000). The same phenomenon was observed with soil polluted by copper-containing fungicides (Filser et al., 2000). In a naturally lead-contaminated site Hågvar and Abrahamsen (1990) classified Folsomia quadrioculata (a nearby species) as tolerant to lead, its abundance being not affected at concentrations as high as $5,000 \mathrm{ppm}$.

Changes in $\mathrm{pH}$ cannot explain the above mentioned movements of collembolan populations from a humus type to another. Although soil $\mathrm{pH}$ was significantly affected by the application of lead acetate, the rise observed at the end of the experiment in the neutral soil was very weak (at most 0.1 $\mathrm{pH}$ unit), thus it was not high enough to force some species to escape from polluted compartments. A possible attraction of acidophilic species by a decrease of $\mathrm{pH}$ in the mull soil can be disregarded for the same reason. We cannot rule out possible toxic (or attractive) effects of the acetate moiety, but the absence of acidification of the soil at the end of the experiment led us to conclude that such effects, if any, were probably temporary. Nevertheless, acetate toxicity could explain at least partly, together with an increase in osmotic pressure of the soil solution (Heungens and Van Daele, 1984), the collapse in collembolan abundance and diversity we observed at high concentration. Lead, acetate and osmotic pressure acted probably both directly and indirectly on soil collembolan communities. Indirect effects could be suspected to occur through changes in predatory pressure (Grelle et al., 2000) and quantity and quality of the microflora (Tranvik and Eijsackers, 1989; Hopkin, 1994) which may have occurred during the two weeks of the experiment. 


\section{References}

Abrahamsen, G., Hovland, J., Hågvar, S., 1980. Effects of artificial acid rain and liming on soil organisms and the decomposition of organic matter. In: Hutchinson, T.C., Havas, M. (Eds.), Effects of acid precipitation on terrestrial ecosystems. Plenum Publishing Corporation, New York, pp. 341-362.

Bååth, E., Berg, B., Lohm, U., Lundgren, B., Lundkvist, H., Rosswall, T., Söderström, B., Wiren, A., 1980. Effects of experimental acidification and liming on soil organisms and decomposition in a Scots pine forest. Pedobiologia 20, 85-100.

Balabane, M., Faivre, D., Van Oort, F., Dahmani-Muller, H., 1999. Mutual effects of soil organic matter dynamics and heavy metals fate in a metallophyte grassland. Environmental Pollution 105, 4554.

Bengtsson, G., Erlandsson, A., Rundgren, S., 1988. Fungal odour attracts soil Collembola. Soil Biolpgy and Biochemistry 20, 25-30.

Berggren, D., Bergkvist, B., Falkengren-Grerup, U., Folkeson, L., Tyler, G., 1990. Metal solubility and pathways in acidified forest ecosystems of South Sweden. The Science of theTotal Environment 96, 103-114.

Bergkvist, B., 1987. Soil solution chemistry and metal budgets of spruce forest ecosystems in S. Sweden. Water, Air, and Soil Pollution 33, 131-154.

Brêthes, A., Brun, J.J., Jabiol, B., Ponge, J.F., Brun, J.J., 1995. Classification of forest humus forms: a French proposal. Annales des Sciences Forestières 52, 535-546. 
Bruus Pedersen, M., Axelsen, J.A., Strandberg, B., Jensen, J., Attrill, M.J., 1999. The impact of a copper gradient on a microarthropod field community. Ecotoxicology 8, 467-483.

Chagnon, M., Hébert, C., Paré, D., 2000. Community structures of Collembola in sugar maple forests: relations to humus type and seasonal trends. Pedobiologia 44, 148-174.

Clarkson, D.T., 1969. Metabolic aspects of aluminium toxicity and some possible mechanisms for resistance. In: Rorison, I.H. (Ed.), Ecological aspects of the mineral nutrition of plants. Blackwell Scientific Publications, Oxford, pp. 381-397.

Crommentuijn, T., Doornekamp, A., Van Gestel, C.A.M., 1997. Bioavailability and ecological effects of cadmium on Folsomia candida (Willem) in an artificial soil substrate as influenced by $\mathrm{pH}$ and organic matter. Applied Soil Ecology 5, 261-271.

Filser, J., Hölscher, G., 1997. Experimental studies on the reactions of Collembola to copper contamination. Pedobiologia 41, 173-178.

Filser, J., Wittmann, R., Lang, A., 2000. Response types in Collembola towards copper in the microenvironment. Environmental Pollution 107, 71-78.

Gisin, H., 1943. Ökologie und Lebengemeinschaften der Collembolen im schweizerischen Exkursionsgebiet Basels. Revue Suisse de Zoologie 50, 131-224.

Glantz, S.A., 1997. Primer of biostatistics, $4^{\text {th }}$ ed. McGraw-Hill, New York, p. 473.

Grelle, C., Fabre, M.C., Leprêtre, A., Descamps, 2000. Myriapod and isopod communities in soils contaminated by heavy metals in northern France. European Journal of Soil Science 51, 425433. 
1 Hågvar, S., 1984. Effect of liming and artificial acid rain on Collembola and Protura in coniferous forest. Pedobiologia 27, 341-254

Hågvar, S., Abrahamsen, G., 1980. Colonisation by Enchytraeidae, Collembola and Acari in sterile soil samples with adjusted pH levels. Oikos 34, 245-258.

Hågvar, S., Abrahamsen, G., 1984. Collembola in Norwegian coniferous forest soils. III. Relations to soil chemistry. Pedobiologia 27, 331-339.

Hågvar, S., Abrahamsen, G., 1990. Microarthropods and Enchytraeidae (Oligochaeta) in naturally lead-contaminated soil: a gradient study. Environmental Entomology 19, 1263-1277.

Hågvar, S., Kjøndal, B.R., 1981. Effects of artificial acid rain on the microarthropod fauna in decomposing birch leaves. Pedobiologia 22, 409-422.

Harasymek, L., Sinha, R.N., 1974. Survival of springtails Hypogastrura tullbergi and Proisotoma minuta on fungal and bacterial diets. Environmental Entomology 3, 965-968.

Heungens, A., Van Daele, E., 1984. The influence of some acids, bases and salts on the mite and Collembola population of a pine litter substrate. Pedobiologia 27, 299-311.

Hopkin, S.P., 1994. Effects of metal pollutants on decomposition processes in terrestrial ecosystems with special reference to fungivorous soil arthropods. In: Ross, S.M. (Ed.), Toxic metals in soilplant systems. John Wiley, Chichester, pp. 303-326.

Hopkin, S.P., 1995. Deficiency and excess of essential and non-essential metals in terrestrial insects. In: Harrington, R., Stork, N.E. (Eds.), Insects in a changing environment. Symposia of the Royal Entomological Society of London 17, 251-270.

Hopkin, S.P., 1997. Biology of the springtails. Oxford University Press, Oxford, p. 330. 
James, B.R., Riha, S.J., 1984. Soluble aluminum in acidified organic horizons of forest soils. Canadian Journal of Soil Science 64, 637-646.

Joosse, E.N.G., Buker, J.B., 1979. Uptake and excretion of lead by litter-dwelling Collembola. Environmental Pollution 18, 235-240.

Loranger, G., Bandyopadhyaya, I., Razaka, B., Ponge, J.F., 2001. Does soil acidity explain altitudinal sequences in collembolan communities? Soil Biology and Biochemistry 33, 381-393.

Lundström, U.S., Van Breemen, N., Bain, D.C., Van Hees, P.A.W., Giesler, R., Gustafsson, J.P., Ilvesniemi, H., Karltun, E., Melkerud, P.A., Olsson, M., Riise, G., Wahlberg, O., Bergelin, A., Bishop, K., Finlay, R., Jongmans, A.G., Magnusson, T., Mannerkoski, H., Nordgren, A., Nyberg, L., Starr, M., Tau Strand, L., 2000. Advances in understanding the podzolization process resulting from a multidisciplinary study of three coniferous forest soils in the Nordic Countries. Geoderma 94, 335-353.

Mateos, E., Selga, D., 1991. Efecto de los incendios forestales sobre las poblaciones de colémbolos edáficos en bosque mediterráneo. Revue d'Écologie et de Biologie du Sol 28, 19-30.

Mertens, J., 1975. L'influence du facteur pH sur le comportement de Orchesella villosa (Geoffroy, 1764) (Collembola, Insecta). Annales de la Société Royale de Zoologie de Belgique 105, 45 52.

Ponge, J.F., 1983. Les Collemboles, indicateurs du type d'humus en milieu forestier. Résultats obtenus au Sud de Paris. Acta Oecologica, Oecologia Generalis 4, 359-374.

Ponge, J.F., 1991. Food resources and diets of soil animals in a small area of Scots pine litter. Geoderma 49, 33-62. 
1 Ponge, J.F., 1993. Biocenoses of Collembola in atlantic temperate grass-woodland ecosystems.

Ponge, J.F., 1999. Horizons and humus forms in beech forests of the Belgian Ardennes. Soil Science Society of America Journal 63, 1888-1901.

Ponge, J.F., 2000a. Acidophilic Collembola: living fossils? Contributions from the Biological Laboratory, Kyoto University 29, 65-74.

Ponge, J.F., 2000b. Vertical distribution of Collembola (Hexapoda) and their food resources in organic horizons of beech forests. Biology and Fertility of Soils 32, 508-522.

Posthuma, L., 1990. Genetic differentiation between populations of Orchesella cincta (Collembola) from heavy metal contaminated sites. Journal of Applied Ecology 27, 609-622.

Posthuma, L., Hogervorst, R.F., Joosse, E.N.G., Van Straalen, N.M., 1993. Genetic variation and covariation for characteristics associated with cadmium tolerance in natural populations of the springtail Orchesella cincta (L.). Evolution 47, 619-631.

Posthuma, L., Hogervorst, R.F., Van Straalen, N.M., 1992. Adaptation to soil pollution by cadmium excretion in natural populations of Orchesella cincta (L.) (Collembola). Archives of Environmental Contamination and Toxicology 22, 146-156.

Rusek, J., 1989. Collembola and Protura in a meadow-forest ecotone. In: Dallai, R. (Ed.), Third international seminar on Apterygota. University of Siena, Siena, pp. 413-418.

Sadaka-Laulan, N., Ponge, J.F., Roquebert, M.F., Bury, E., Boumezzough, A., 1998. Feeding preferences of the collembolan Onychiurus sinensis for fungi colonizing holm oak litter (Quercus rotundifolia Lam.). European Journal of Soil Biology 34, 179-188. 
Sarret, G., Manceau, A., Hazemann, J.L., Gomez, A., Mench, M., 1997. EXAFS study of the nature of zinc complexation sites in humic substances as a function of $\mathrm{Zn}$ concentration. Journal de Physique, Section IV 7, 799-802.

Tranvik, L., Bengtsson, G., Rundgren, S., 1993. Relative abundance and resistance traits of two Collembola species under metal stress. Journal of Applied Ecology 30, 43-52.

Tranvik, L., Eijsackers, H., 1989. On the advantage of Folsomia fimetarioides over Isotomiella minor (Collembola) in a metal polluted soil. Oecologia 80, 195-200.

Tranvik, L., Sjögren, M., Bengtsson, G., 1994. Allozyme polymorphism and protein profile in Orchesella bifasciata (Collembola): indicative of extended metal pollution? Biochemical Systematics and Ecology 22, 13-23.

Van Straalen, N.M., Verhoef, H.A., 1997. The development of a bioindicator system for soil acidity based on arthropod pH preferences. Journal of Applied Ecology 34, 217-232.

Verschueren, K., 2001. Handbook of environmental data on organic chemicals, $4^{\text {th }}$ ed. John Wiley and Sons, New York.

Vilkamaa, P., Huhta, V., 1986. Effects of fertilization and pH on communities of Collembola in pine forest soil. Annali Zoologici Fennici 23, 167-174. 


\section{1}

2

3

\section{Figure captions}

Fig. 1 Abundance of Collembola (mean and standard error of five replicates) in experimental compartments $\left(1 \mathrm{dm}^{3}\right.$ each). $\mathrm{E}=$ Eumull. $\mathrm{D}=$ Dysmoder. $\mathrm{E} 0=$ Eumull without lead. $\mathrm{E} 1=$ Eumull with 50 ppm lead. E2 = Eumull with 6,000 ppm lead. E3 = Eumull with 60,000 ppm lead. Opposite bars relate to adjacent compartments

Fig. 2 Number of species of Collembola (mean and standard error of five replicates) in experimental compartments $\left(1 \mathrm{dm}^{3}\right.$ each). $\mathrm{E}=$ Eumull. $\mathrm{D}=$ Dysmoder. $\mathrm{E} 0=$ Eumull without lead. $\mathrm{E} 1=$ Eumull with 50 ppm lead. E2 = Eumull with 6,000 ppm lead. E3 = Eumull with 60,000 ppm lead. Opposite bars relate to adjacent compartments

Fig. 3 Abundance of Folsomia manolachei (mean and standard error of five replicates) in experimental compartments $\left(1 \mathrm{dm}^{3}\right.$ each $) . E=$ Eumull. $\mathrm{D}=$ Dysmoder. $\mathrm{E} 0=$ Eumull without lead. $\mathrm{E} 1=$ Eumull with 50 ppm lead. E2 = Eumull with 6,000 ppm lead. E3 = Eumull with 60,000 ppm lead. Opposite bars relate to adjacent compartments

Fig. 4 Abundance of Parisotoma notabilis (mean and standard error of five replicates) in experimental compartments $\left(1 \mathrm{dm}^{3}\right.$ each $) . E=$ Eumull. $\mathrm{D}=$ Dysmoder. $\mathrm{E} 0=$ Eumull without lead. $\mathrm{E} 1=$ Eumull with 50 ppm lead. E2 = Eumull with 6,000 ppm lead. E3 = Eumull with 60,000 ppm lead. Opposite bars relate to adjacent compartments 
Table 1. List of collembolan species found in the experiment, 0 : absence, 1 : presence

\begin{tabular}{|c|c|c|c|c|}
\hline & Eumull & Dysmoder & Ubiquitous & Dubious \\
\hline Allacma fusca (Linné, 1758) & 1 & 0 & 0 & 0 \\
\hline Arrhopalites caecus (Tullberg, 1871) & 1 & 0 & 0 & 0 \\
\hline Arrhopalites sericus Gisin, 1947 & 0 & 1 & 0 & 0 \\
\hline Dicyrtoma fusca (Lucas, 1842) & 0 & 0 & 1 & 0 \\
\hline Dicyrtomina minuta (Fabricius, 1783) & 1 & 0 & 0 & 0 \\
\hline Folsomia manolachei Bagnall 1939 & 0 & 0 & 1 & 0 \\
\hline Friesea truncata Cassagnau, 1958 & 0 & 0 & 1 & 0 \\
\hline Heteromurus nitidus (Templeton, 1835) & 1 & 0 & 0 & 0 \\
\hline Isotomiella minor (Schäffer, 1896) & 0 & 0 & 1 & 0 \\
\hline Isotomurus palustris (Müller, 1776) & 1 & 0 & 0 & 0 \\
\hline Kalaphorura burmeisteri (Lubbock, 1873) & 1 & 0 & 0 & 0 \\
\hline Lepidocyrtus lanuginosus (Gmelin, 1788) & 0 & 0 & 1 & 0 \\
\hline Megalothorax minimus (Willem, 1900) & 0 & 0 & 1 & 0 \\
\hline Mesaphorura gr krausbaueri (Börner, 190 & 0 & 0 & 1 & 0 \\
\hline Mesaphorura gr sylvatica (Rusek, 1971) & 1 & 0 & 0 & 0 \\
\hline Mesaphorura gr yosii (Rusek, 1967) & 0 & 0 & 1 & 0 \\
\hline Micranurida pygmaea (Börner, 1901) & 0 & 1 & 0 & 0 \\
\hline Monobella grassei (Denis, 1923) & 1 & 0 & 0 & 0 \\
\hline Neanura muscorum (Templeton, 1835) & 1 & 0 & 0 & 0 \\
\hline Onychiurus pseudogranulosus Gisin, 1951 & & 0 & 0 & 0 \\
\hline Orchesella cincta (Linné, 1758) & 1 & 0 & 0 & 0 \\
\hline Paratullbergia callipygos (Börner, 1902) & 0 & 0 & 1 & 0 \\
\hline Parisotoma notabilis (Schäffer, 1896) & 1 & 0 & 0 & 0 \\
\hline Proisotoma minima (Absolon, 1901) & 0 & 1 & 0 & 0 \\
\hline Pseudachorutes parvulus Böener, 1901 & 1 & 0 & 0 & 0 \\
\hline Pseudosinella alba (Packard, 1873) & 1 & 0 & 0 & 0 \\
\hline Pseudosinella mauli Stomp, 1972 & 0 & 1 & 0 & 0 \\
\hline Sminthurinus aureus (Lubbock, 1862) & 1 & 0 & 0 & 0 \\
\hline Sminthurinus signatus (Krausbauer, 1898) & 0 & 1 & 0 & 0 \\
\hline Sphaeridia pumilis (Krausbauer, 1898) & 0 & 0 & 1 & 0 \\
\hline Stenaphorurella denisi (Bagnall, 1935) & 1 & 0 & 0 & 0 \\
\hline Tomocerus minor (Lubbock, 1862) & 0 & 0 & 1 & 0 \\
\hline Willemia anophthalma Börner, 1901 & 0 & 1 & 0 & 0 \\
\hline Willemia buddenbrocki Hüther, 1959 & 1 & 0 & 0 & 0 \\
\hline Xenylla grisea Axelson, 1900 & 1 & 0 & 0 & 0 \\
\hline Xenylla tullbergi Börner, 1903 & 0 & 1 & 0 & 0 \\
\hline Xenyllodes armatus (Axelson, 1903) & 0 & 0 & 0 & 1 \\
\hline
\end{tabular}


Table 2. Mean abundance ( \pm S.E.) of most frequent collembolan species and groups of species and water $\mathrm{pH}$ in Eumull and Dysmoder at the end of the experiment. Means followed by a common letter indicate groups which do not differ significantly. $E=$ Eumull species, $\mathrm{D}=$ Dysmoder species, $\mathrm{U}=$ ubiquitous species

\begin{tabular}{|c|c|c|c|}
\hline & & Eumull & Dysmoder \\
\hline$U$ & Dicyrtoma fusca & $1.8 \pm 0.6$ & $0.6 \pm 0.2$ \\
\hline $\mathrm{U}$ & Folsomia manolachei & $18.5 \pm 1.3 b$ & $113.4 \pm 18.6 a$ \\
\hline U & Friesea truncata & $0.5 \pm 0.3$ & $0.6 \pm 0.1$ \\
\hline $\mathrm{E}$ & Heteromurus nitidus & $1.3 \pm 0.3 a$ & Ob \\
\hline U & Isotomiella minor & $51.3 \pm 3.8 \mathrm{a}$ & $25.7 \pm 3.4 b$ \\
\hline $\mathrm{U}$ & Lepidocyrtus lanuginosus & $1.6 \pm 0.3 b$ & $4.8 \pm 0.6 a$ \\
\hline $\mathrm{U}$ & Megalothorax minimus & $0.5 \pm 0.5 b$ & $8.9 \pm 0.6 a$ \\
\hline D & Micranurida pygmaea & Ob & $1.9 \pm 0.6 a$ \\
\hline $\mathrm{U}$ & Paratullbergia callipygos & $0.6 \pm 0.3 b$ & $3.1 \pm 0.5 a$ \\
\hline $\mathrm{E}$ & Parisotoma notabilis & $8.7 \pm 1.3 a$ & Ob \\
\hline D & Proisotoma minima & ob & $0.4 \pm 0.1 a$ \\
\hline $\mathrm{E}$ & Pseudosinella alba & $2.0 \pm 0.4 a$ & Ob \\
\hline D & Pseudosinella mauli & ob & $0.7 \pm 0.3 a$ \\
\hline D & Sminthurinus signatus & $\mathbf{O b}$ & $1.4 \pm 0.3 a$ \\
\hline U & Sphaeridia pumilis & $2.1 \pm 0.7$ & $2.9 \pm 0.5$ \\
\hline D & Willemia anophthalma & $\mathbf{O b}$ & $28.6 \pm 3.0 \mathrm{a}$ \\
\hline \multirow[t]{10}{*}{$\mathrm{D}$} & Xenylla tullbergi & $\mathbf{O b}$ & $0.3 \pm 0.1 \mathrm{a}$ \\
\hline & Total abundance & $90.4 \pm 5.5 b$ & $194.6 \pm 17.2 a$ \\
\hline & Abundance of Eumull species & $13.3 \pm 1.6 a$ & $\mathbf{O b}$ \\
\hline & Abundance of Dysmoder spec & Ob & $33.3 \pm 2.5 \mathrm{a}$ \\
\hline & Abundance of ubiquitous spec & $77.1 \pm 4.4 b$ & $161.3 \pm 16.4 a$ \\
\hline & Total number of species & $8.9 \pm 0.4 b$ & $12.0 \pm 0.3 a$ \\
\hline & Number of Eumull species & $4.8 \pm 0.5 a$ & $\mathbf{O b}$ \\
\hline & Number of Dysmoder species & ob & $5.2 \pm 0.4 a$ \\
\hline & Number of ubiquitous species & $6.4 \pm 0.7 \mathrm{~b}$ & $9.6 \pm 0.5 a$ \\
\hline & Water $\mathrm{pH}$ & $7.66 \pm 0.03 a$ & $4.29 \pm 0.01 b$ \\
\hline
\end{tabular}


Table 3. Mean abundance ( \pm S.E.) of most frequent collembolan species and groups of species and water $\mathrm{pH}$ in Eumull after application of lead acetate in the two compartments of experimental boxes, compared to control boxes without addition of lead. Means followed by a common letter indicate groups which do not differ significantly. $\mathrm{E}=$ Eumull species, $\mathrm{U}=$ ubiquitous species. $\mathrm{E} 0 / \mathrm{E} 0=\mathrm{No} \mathrm{Pb}$, $\mathrm{E} 1 / \mathrm{E} 1=\mathrm{Pb}$ at $50 \mathrm{ppm}, \mathrm{E} 2 / \mathrm{E} 2=\mathrm{Pb}$ at $6,000 \mathrm{ppm}, \mathrm{E} 3 / \mathrm{E} 3=\mathrm{Pb}$ at $60,000 \mathrm{ppm}$

\begin{tabular}{|c|c|c|c|c|c|}
\hline & & E0/E0 & $\mathrm{E} 1 / \mathrm{E} 1$ & E2/E2 & E3/E3 \\
\hline U & Dicyrtoma fusca & $1.8 \pm 0.6$ & $1.2 \pm 0.3$ & $2.0 \pm 0.7$ & $0.5 \pm 0.2$ \\
\hline$U$ & Folsomia manolachei & $18.5 \pm 1.3 a$ & $13.3 \pm 1.8 b$ & $8.1 \pm 1.0 c$ & $0.9 \pm 0.7 d$ \\
\hline $\mathrm{U}$ & Friesea truncata & $0.5 \pm 0.3 a b$ & $1.5 \pm 0.5 a$ & $1.6 \pm 0.4 a$ & ob \\
\hline $\mathrm{E}$ & Heteromurus nitidus & $1.3 \pm 0.3 a$ & $0.6 \pm 0.2 \mathrm{ab}$ & $1.0 \pm 0.2 \mathrm{ab}$ & $0.3 \pm 0.2 b$ \\
\hline U & Isotomiella minor & $51.3 \pm 3.8 \mathrm{a}$ & $53.7 \pm 10.6 a$ & $46.8 \pm 7.9 a$ & $0.7 \pm 0.7 b$ \\
\hline U & Lepidocyrtus lanuginosus & $1.6 \pm 0.3 a$ & $1.3 \pm 0.4 a$ & $1.2 \pm 0.3 a$ & $0.2 \pm 0.1 b$ \\
\hline$U$ & Megalothorax minimus & $0.5 \pm 0.5$ & $0.1 \pm 0.1$ & 0 & 0 \\
\hline U & Paratullbergia callipygos & $0.6 \pm 0.3 b c$ & $1.0 \pm 0.2 b$ & $1.9 \pm 0.4 a$ & $0 c$ \\
\hline $\mathrm{E}$ & Parisotoma notabilis & $8.7 \pm 1.3 a$ & $5.8 \pm 0.3 a$ & $2.3 \pm 0.3 b$ & $0.2 \pm 0.2 c$ \\
\hline $\mathrm{E}$ & sinella alba & $2.0 \pm 0.4 a$ & $1.3 \pm 0.3 a b$ & $0.6 \pm 0.3 b c$ & oc \\
\hline \multirow[t]{8}{*}{ U } & Sphat & $2.1 \pm 0.7 a$ & $1.3 \pm 0.5 \mathrm{ab}$ & $0.3 \pm 0.3 b$ & $\mathbf{O b}$ \\
\hline & Total & $90.4 \pm 5.5 a$ & $86.3 \pm 14.5 a$ & $68.3 \pm 9.6 a$ & $2.8 \pm 1.5 b$ \\
\hline & Abundance of Eumull species & $13.3 \pm 1.6 a$ & $12.7 \pm 1.3 a$ & $6.4 \pm 0.7 b$ & $0.5 \pm 0.2 c$ \\
\hline & ce of ubiquitous spec & $77.1 \pm 4.4 a$ & $73.6 \pm 13.7 a$ & $61.9 \pm 9.0 a$ & $2.3 \pm 1.3 b$ \\
\hline & oer of species & $8.9 \pm 0.4 a$ & $10.3 \pm 0.9 a$ & $9.1 \pm 0.3 a$ & $1.5 \pm 0.5 b$ \\
\hline & Num & $4.8 \pm 0.5 a$ & $6.4 \pm 0.7 a$ & $5.8 \pm 1.0 \mathrm{a}$ & $0.6 \pm 0.2 b$ \\
\hline & Number of ubiquitous species & $6.4 \pm 0.7 a$ & $6.8 \pm 0.7 a$ & $6.0 \pm 0.0 \mathrm{a}$ & $2.0 \pm 0.6 b$ \\
\hline & Water $\mathrm{pH}$ & $7.66 \pm 0.03 b$ & $7.63 \pm 0.03 b$ & $7.65 \pm 0.01 b$ & $7.8 \pm 0.02 a$ \\
\hline
\end{tabular}


Table 4. Mean abundance ( $\pm S$.E.) of most frequent collembolan species and groups of species and water $\mathrm{pH}$ in unpolluted Eumull after application of lead acetate in the adjacent Eumull compartment, compared to control boxes without addition of lead.

Means followed by a common letter indicate groups which do not differ significantly. $E=$ Eumull species, $\mathrm{U}=$ ubiquitous species. $\mathrm{E} 0 / \mathrm{E} 0=\mathrm{No} \mathrm{Pb}, \mathrm{E} 0 / \mathrm{E} 1=\mathrm{Pb}$ at $50 \mathrm{ppm}, \mathrm{E} 0 / \mathrm{E} 2$ $=\mathrm{Pb}$ at $6,000 \mathrm{ppm}, \mathrm{E} 0 / \mathrm{E} 3=\mathrm{Pb}$ at $60,000 \mathrm{ppm}$

\begin{tabular}{|c|c|c|c|c|c|}
\hline & & E0/E0 & E0/E1 & E0/E2 & E0/E3 \\
\hline$U$ & Dicyrtoma fusca & $1.8 \pm 0.6$ & $1.4 \pm 0.4$ & $1.8 \pm 0.4$ & $0.8 \pm 0.6$ \\
\hline U & Folsomia manolachei & $18.5 \pm 1.3 a$ & $16.8 \pm 1.9 a b$ & $12.4 \pm 0.5 b c$ & $9.6 \pm 2.1 \mathrm{c}$ \\
\hline $\mathrm{U}$ & Friesea truncata & $0.5 \pm 0.3$ & $1.0 \pm 0.8$ & $0.8 \pm 0.4$ & $0.8 \pm 0.4$ \\
\hline $\mathrm{E}$ & Heteromurus nitidus & $1.3 \pm 0.3 a$ & $0.4 \pm 0.2 b$ & $0.6 \pm 0.2 a b$ & $\mathbf{O b}$ \\
\hline $\mathrm{U}$ & Isotomiella minor & $51.3 \pm 3.8$ & $59.2 \pm 10.5$ & $51.2 \pm 10.2$ & $33.2 \pm 7.7$ \\
\hline $\mathrm{U}$ & Lepidocyrtus lanuginosus & $1.6 \pm 0.3$ & $1.4 \pm 0.5$ & $1.6 \pm 0.4$ & $1.4 \pm 0.7$ \\
\hline $\mathrm{U}$ & Megalothorax minimus & $0.5 \pm 0.5 \mathrm{ab}$ & $1.0 \pm 0.3 a$ & Ob & $\mathbf{O b}$ \\
\hline $\mathrm{U}$ & Paratullbergia callipygos & $0.6 \pm 0.3$ & $0.4 \pm 0.2$ & $1.6 \pm 0.7$ & $1.6 \pm 0.6$ \\
\hline $\mathrm{E}$ & Parisotoma notabilis & $8.7 \pm 1.3$ & $7.8 \pm 0.7$ & $8.8 \pm 2.7$ & $3.8 \pm 0.9$ \\
\hline $\mathrm{E}$ & Pseudosinella alba & $2.0 \pm 0.4$ & $1.8 \pm 0.6$ & $1.4 \pm 0.5$ & $0.6 \pm 0.4$ \\
\hline \multirow[t]{8}{*}{ U } & Sphaeridia pumilis & $2.1 \pm 0.7$ & $1.4 \pm 0.5$ & $1.6 \pm 0.9$ & $0.8 \pm 0.2$ \\
\hline & Total abundance & $90.4 \pm 5.5$ & $94.0 \pm 13.8$ & $84.6 \pm 8.9$ & $55.2 \pm 8.5$ \\
\hline & Abundance of Eumull species & $13.3 \pm 1.6$ & $11.2 \pm 0.9$ & $13.6 \pm 2.7$ & $6.8 \pm 2.2$ \\
\hline & Abundance of ubiquitous spec & $77.1 \pm 4.4$ & $82.8 \pm 13.1$ & $71.0 \pm 9.7$ & $48.4 \pm 8.6$ \\
\hline & Total number of species & $8.9 \pm 0.4$ & $9.4 \pm 0.9$ & $10.8 \pm 0.7$ & $8.6 \pm 0.9$ \\
\hline & Number of Eumull species & $4.8 \pm 0.5$ & $3.2 \pm 0.5$ & $4.8 \pm 0.6$ & $3.2 \pm 0.9$ \\
\hline & Number of ubiquitous species & $6.4 \pm 0.7$ & $6.2 \pm 0.6$ & $6.0 \pm 0.4$ & $5.4 \pm 0.6$ \\
\hline & Water $\mathrm{pH}$ & $7.66 \pm 0.03$ & $7.68 \pm 0.01$ & $7.66 \pm 0.02$ & $7.78 \pm 0.02$ \\
\hline
\end{tabular}


Table 5. Mean abundance ( \pm S.E.) of most frequent collembolan species and groups of species and water $\mathrm{pH}$ in lead acetate-polluted Eumull adjacent to unpolluted Eumull, compared to control boxes without any addition of lead in both compartments. Means followed by a common letter indicate groups which do not differ significantly. $E=$ Eumull species, $U=$ ubiquitous species. $E 0 / E 0=$ No $\mathrm{Pb}, \mathrm{E} 1 / \mathrm{E} 0=\mathrm{Pb}$ at $50 \mathrm{ppm}, \mathrm{E} 2 / \mathrm{E} 0=\mathrm{Pb}$ at $6,000 \mathrm{ppm}, \mathrm{E} 3 / \mathrm{E} 0=\mathrm{Pb}$ at $60,000 \mathrm{ppm}$

\begin{tabular}{|c|c|c|c|c|c|}
\hline & & E0/E0 & E1/E0 & E2/E0 & E3/E0 \\
\hline$U$ & Dicyrtoma fusca & $1.8 \pm 0.6$ & $1.4 \pm 0.4$ & $1.6 \pm 0.4$ & $0.8 \pm 0.6$ \\
\hline$U$ & Folsomia manolachei & $18.5 \pm 1.3 a$ & $14.6 \pm 0.7 a$ & $14.8 \pm 2.0 \mathrm{a}$ & $1.2 \pm 0.7 b$ \\
\hline$U$ & Friesea truncata & $0.5 \pm 0.3 b$ & $0.8 \pm 0.5 b$ & $2.0 \pm 0.4 a$ & $0.2 \pm 0.2 b$ \\
\hline $\mathrm{E}$ & Heteromurus nitidus & $1.3 \pm 0.3$ & $0.6 \pm 0.4$ & $0.6 \pm 0.2$ & $0.2 \pm 0.2$ \\
\hline$U$ & Isotomiella minor & $51.3 \pm 3.8 \mathrm{a}$ & $52.6 \pm 8.4 a$ & $50.0 \pm 13.6 a$ & $1.4 \pm 0.7 b$ \\
\hline$U$ & Lepidocyrtus lanuginosus & $1.6 \pm 0.3$ & $1.6 \pm 0.7$ & $2.6 \pm 1.2$ & $1.8 \pm 0.7$ \\
\hline$U$ & Megalothorax minimus & $0.5 \pm 0.5$ & $0.8 \pm 0.5$ & $0.4 \pm 0.4$ & 0 \\
\hline $\mathrm{U}$ & Paratullbergia callipygos & $0.6 \pm 0.3$ & $0.8 \pm 0.4$ & $0.8 \pm 0.4$ & 0 \\
\hline $\mathrm{E}$ & Parisotoma notabilis & $8.7 \pm 1.3 a$ & $6.0 \pm 0.6 b$ & $5.2 \pm 1.0 \mathrm{~b}$ & $0.4 \pm 0.4 c$ \\
\hline $\mathrm{E}$ & Pseudosinella alba & $2.0 \pm 0.4 a$ & $1.6 \pm 0.4 a b$ & $1.0 \pm 0.5 a b$ & $0.2 \pm 0.2 b$ \\
\hline \multirow[t]{8}{*}{$U$} & Sphaeridia pumilis & $2.1 \pm 0.7$ & $1.6 \pm 0.9$ & $1.4 \pm 0.7$ & $0.4 \pm 0.2$ \\
\hline & Total abundance & $90.4 \pm 5.5 a$ & $84.0 \pm 9.7 a$ & $85.8 \pm 15.2 a$ & $7.8 \pm 2.0 \mathrm{~b}$ \\
\hline & Abundance of Eumull species & $13.3 \pm 1.6 a$ & $9.6 \pm 1.0 \mathrm{a}$ & $12.2 \pm 2.6 \mathrm{a}$ & $2.0 \pm 0.7 b$ \\
\hline & Abundance of ubiquitous spec & $77.1 \pm 4.4 a$ & $74.4 \pm 9.1 \mathrm{a}$ & $73.6 \pm 14.0 \mathrm{a}$ & $5.8 \pm 2.0 \mathrm{~b}$ \\
\hline & Total number of species & $8.9 \pm 0.4 a$ & $9.0 \pm 0.7 a$ & $10.8 \pm 1.0 \mathrm{a}$ & $4.8 \pm 0.7 b$ \\
\hline & Number of Eumull species & $4.8 \pm 0.5 a$ & $3.4 \pm 0.7 a b$ & $4.6 \pm 0.9 a$ & $1.6 \pm 0.5 b$ \\
\hline & Number of ubiquitous species & $6.4 \pm 0.7 a$ & $5.8 \pm 0.4 a$ & $6.2 \pm 0.7 a$ & $3.0 \pm 0.8 b$ \\
\hline & Water pH & $7.66 \pm 0.03$ & $7.67 \pm 0.01$ & $7.73 \pm 0.04$ & $7.73 \pm 0.05$ \\
\hline
\end{tabular}


Table 6. Mean abundance ( \pm S.E.) of most frequent collembolan species and groups of species and water $\mathrm{pH}$ in Eumull adjacent to Dysmoder, at different levels of lead application in Eumull, compared to control boxes with unpolluted Eumull in both compartments. Means followed by a common letter indicate groups which do not differ significantly. $E=$ Eumull species, $D=$ Dysmoder species, $\mathrm{U}=$ ubiquitous species. $\mathrm{E} 0 / \mathrm{E} 0$ and $\mathrm{E} 0 / \mathrm{D}=\mathrm{No} \mathrm{Pb}, \mathrm{E} 1 / \mathrm{D}=\mathrm{Pb}$ at $50 \mathrm{ppm}, \mathrm{E} 2 / \mathrm{D}=\mathrm{Pb}$ at $6,000 \mathrm{ppm}, \mathrm{E} 3 / \mathrm{D}=\mathrm{Pb}$ at $60,000 \mathrm{ppm}$

\begin{tabular}{|c|c|c|c|c|c|c|}
\hline & & E0/E0 & E0/D & $E 1 / D$ & $E 2 / D$ & $\mathrm{E} 3 / \mathrm{D}$ \\
\hline$U$ & Dicyrtoma fusca & $1.8 \pm 0.6$ & $1.6 \pm 0.7$ & $1.4 \pm 0.5$ & $1.0 \pm 0.6$ & $0.8 \pm 0.4$ \\
\hline$U$ & Folsomia manolachei & $18.5 \pm 1.3 a$ & $12.4 \pm 1.5 a$ & $12.2 \pm 1.7 a$ & $18.8 \pm 3.9 a$ & $5.6 \pm 0.6 b$ \\
\hline$U$ & Friesea truncata & $0.5 \pm 0.3 a b$ & $0.4 \pm 0.2 \mathrm{ab}$ & $1.4 \pm 0.5 \mathrm{ab}$ & $2.0 \pm 0.7 a$ & Ob \\
\hline $\mathrm{E}$ & Heteromurus nitidus & $1.3 \pm 0.3$ & $0.6 \pm 0.4$ & $0.2 \pm 0.2$ & $0.4 \pm 0.2$ & $0.2 \pm 0.2$ \\
\hline$U$ & Isotomiella minor & $51.3 \pm 3.8 \mathrm{ab}$ & $38.4 \pm 6.4 b$ & $69.0 \pm 10.8 a$ & $57.6 \pm 6.6 \mathrm{ab}$ & $2.0 \pm 0.4 \mathrm{c}$ \\
\hline$U$ & Lepidocyrtus lanuginosus & $1.6 \pm 0.3 b$ & $2.2 \pm 0.4 b$ & $3.2 \pm 1.0 \mathrm{ab}$ & $7.6 \pm 2.3 a$ & $3.6 \pm 0.4 a$ \\
\hline$U$ & Megalothorax minimus & $0.5 \pm 0.5 \mathrm{ab}$ & Ob & $1.2 \pm 0.4 a$ & $0.4 \pm 0.2 a b$ & $\mathrm{Ob}$ \\
\hline D & Micranurida pygmaea & 0 & 0 & 0 & $0.2 \pm 0.2$ & 0 \\
\hline$U$ & Paratullbergia callipygos & $0.6 \pm 0.3 a b$ & $2.4 \pm 1.0 \mathrm{a}$ & $0.6 \pm 0.4 a b$ & $0.6 \pm 0.2 a b$ & $\mathbf{O b}$ \\
\hline $\mathrm{E}$ & Parisotoma notabilis & $8.7 \pm 1.3 a$ & $6.2 \pm 1.6 \mathrm{ab}$ & $6.2 \pm 2.2 \mathrm{ab}$ & $3.0 \pm 0.8 b$ & $1.6 \pm 0.7 b$ \\
\hline $\mathrm{E}$ & Pseudosinella alba & $2.0 \pm 0.4 a$ & $0.2 \pm 0.2 b$ & $0.4 \pm 0.2 b$ & $1.2 \pm 0.4 a b$ & $0.2 \pm 0.2 b$ \\
\hline D & Pseudosinella mauli & 0 & $0.2 \pm 0.2$ & $0.2 \pm 0.2$ & 0 & 0 \\
\hline D & Sminthurinus signatus & 0 & $0.2 \pm 0.2$ & 0 & 0 & 0 \\
\hline$U$ & Sphaeridia pumilis & $2.1 \pm 0.7$ & $1.6 \pm 0.4$ & $0.6 \pm 0.2$ & $0.8 \pm 0.6$ & $0.8 \pm 0.2$ \\
\hline D & Willemia anophthalma & 0 & 0 & $0.2 \pm 0.2$ & $0.6 \pm 0.6$ & $1.6 \pm 0.7$ \\
\hline \multirow[t]{10}{*}{ D } & Xenylla tullbergi & 0 & 0 & $0.2 \pm 0.2$ & $1.6 \pm 1.6$ & $0.2 \pm 0.2$ \\
\hline & Total abundance & $90.4 \pm 5.5 a b$ & $70.0 \pm 6.3 b$ & $99.6 \pm 11.2 a$ & $97.8 \pm 6.1 a$ & $17.4 \pm 2.6 \mathrm{c}$ \\
\hline & Abundance of Eumull species & $13.3 \pm 1.6 a$ & $10.4 \pm 1.1 \mathrm{a}$ & $9.2 \pm 3.0 \mathrm{a}$ & $5.8 \pm 0.7 a$ & $2.4 \pm 1.0 \mathrm{~b}$ \\
\hline & Abundance of Dysmoder spec & & $0.4 \pm 0.4$ & $0.6 \pm 0.4$ & $2.4 \pm 1.7$ & $2.0 \pm 0.9$ \\
\hline & Abundance of ubiquitous spec & $77.1 \pm 4.4 a$ & $59.2 \pm 5.7 b$ & $89.8 \pm 10.8 a$ & $89.0 \pm 6.6 a$ & $13.0 \pm 1.2 \mathrm{c}$ \\
\hline & Total number of species & $8.9 \pm 0.4$ & $10.8 \pm 1.0$ & $9.8 \pm 0.9$ & $9.6 \pm 1.1$ & $7.2 \pm 1.0$ \\
\hline & Number of Eumull species & $4.8 \pm 0.5 a$ & $4.2 \pm 0.7 a$ & $2.8 \pm 0.6 \mathrm{ab}$ & $3.2 \pm 0.5 a b$ & $1.6 \pm 0.5 b$ \\
\hline & Number of Dysmoder species & 0 & $0.4 \pm 0.4$ & $0.6 \pm 0.4$ & $0.6 \pm 0.4$ & $1.0 \pm 0.5$ \\
\hline & Number of ubiquitous species & $6.4 \pm 0.7$ & $6.2 \pm 0.5$ & $6.4 \pm 0.7$ & $5.8 \pm 0.8$ & $4.6 \pm 0.4$ \\
\hline & Water $\mathrm{pH}$ & $7.66 \pm 0.03 b$ & $7.64 \pm 0.03 b$ & $7.61 \pm 0.01 b$ & $7.68 \pm 0.02 b$ & $7.78 \pm 0.05 a$ \\
\hline
\end{tabular}


Table 7. Mean abundance ( \pm S.E.) of most frequent Collembolan species and groups of species and water $\mathrm{pH}$ in Dysmoder adjacent to Eumull, at different levels of lead application in Eumull, compared to control boxes with Dysmoder in both compartments. Means followed by a common letter indicate groups which do not differ significantly. $E=$ Eumull species, $D=$ Dysmoder species, $U=$ ubiquitous species. $E 0 / E 0$ and $E 0 / D=N o P b, E 1 / D=P b$ at 50 ppm, E2/D = Pb at 6,000 ppm, E3/D = Pb at 60,000 ppm

\begin{tabular}{|c|c|c|c|c|c|c|}
\hline & & $\mathrm{D} / \mathrm{D}$ & D/E0 & $\mathrm{D} / \mathrm{E} 1$ & $\mathrm{D} / \mathrm{E} 2$ & D/E3 \\
\hline U & Dicyrtoma fusca & $0.6 \pm 0.2$ & $1.2 \pm 0.5$ & 0 & $1.2 \pm 0.4$ & $1.0 \pm 0.0$ \\
\hline U & Folsomia manolachei & $113.4 \pm 18.6 a b$ & $152.2 \pm 12.0 \mathrm{ab}$ & $182.6 \pm 23.6 a$ & $105.6 \pm 6.4 b$ & $116.6 \pm 23.2 a b$ \\
\hline U & Friesea truncata & $0.6 \pm 0.1$ & $1.2 \pm 0.6$ & $1.4 \pm 0.4$ & $0.4 \pm 0.4$ & $1.8 \pm 0.5$ \\
\hline$E$ & Heteromurus nitidus & 0 & 0 & 0 & 0 & $0.2 \pm 0.2$ \\
\hline U & Isotomiella minor & $25.7 \pm 3.4 b$ & $29.4 \pm 3.2 b$ & $37.4 \pm 6.2 b$ & $84.6 \pm 7.7 a$ & $43.0 \pm 11.6 b$ \\
\hline U & Lepidocyrtus lanuginosus & $4.8 \pm 0.6 b$ & $5.4 \pm 1.3 b$ & $7.4 \pm 1.2 b$ & $4.4 \pm 0.9 b$ & $13.2 \pm 1.1 \mathrm{a}$ \\
\hline U & Megalothorax minimus & $8.9 \pm 0.6 b$ & $8.6 \pm 0.8 b$ & $9.6 \pm 0.8 b$ & $12.4 \pm 1.4 a$ & $4.6 \pm 0.5 c$ \\
\hline D & Micranurida pygmaea & $1.9 \pm 0.6$ & $2.2 \pm 0.5$ & $1.4 \pm 0.7$ & $1.2 \pm 0.8$ & $0.6 \pm 0.4$ \\
\hline U & Paratullbergia callipygos & $3.1 \pm 0.5 a$ & $2.6 \pm 0.9 \mathrm{ab}$ & $0.4 \pm 0.2 c$ & $2.2 \pm 0.7 a b$ & $0.8 \pm 0.2 b c$ \\
\hline$E$ & Parisotoma notabilis & Oc & $1.0 \pm 0.4 \mathrm{c}$ & $10.6 \pm 3.6 b$ & $24.4 \pm 4.5 a$ & $22.0 \pm 5.1 a$ \\
\hline D & Proisotoma minima & $0.4 \pm 0.1 b$ & $3.0 \pm 1.1 \mathrm{ab}$ & $6.0 \pm 0.6 a$ & $5.0 \pm 1.4 a b$ & $6.4 \pm 1.9 a$ \\
\hline D & Pseudosinella mauli & $0.7 \pm 0.3$ & $0.8 \pm 0.4$ & $0.8 \pm 0.5$ & $0.4 \pm 0.2$ & $0.4 \pm 0.2$ \\
\hline D & Sminthurinus signatus & $1.4 \pm 0.3$ & $1.0 \pm 0.4$ & $1.0 \pm 0.3$ & $0.6 \pm 0.2$ & $1.8 \pm 0.6$ \\
\hline U & Sphaeridia pumilis & $2.9 \pm 0.5$ & $2.6 \pm 1.1$ & $1.6 \pm 0.7$ & $0.6 \pm 0.4$ & $0.8 \pm 0.2$ \\
\hline D & Willemia anophthalma & $28.6 \pm 3.0 a$ & $18.8 \pm 2.6 b c$ & $20.8 \pm 5.9 a b c$ & $10.8 \pm 2.5 c$ & $17.4 \pm 0.9 b$ \\
\hline \multirow[t]{10}{*}{ D } & Xenylla tullbergi & $0.3 \pm 0.1 \mathrm{c}$ & $4.6 \pm 2.2$ & $1.6 \pm 1.1$ & $8.4 \pm 5.7$ & $1.8 \pm 1.0$ \\
\hline & Total abundance & $194.6 \pm 17.2 b$ & $235.8 \pm 11.0 a b$ & $284.8 \pm 22.0 \mathrm{a}$ & $264.4 \pm 12.2 a$ & $235.8 \pm 43.6 a b$ \\
\hline & Abundance of Eumull species & $\mathbf{O c}$ & $1.2 \pm 0.5 c$ & $11.2 \pm 3.7 b$ & $24.6 \pm 4.6 a$ & $24.6 \pm 6.2 a$ \\
\hline & Abundance of Dysmoder spec & $33.3 \pm 2.5$ & $30.4 \pm 4.0$ & $32.2 \pm 7.1$ & $26.4 \pm 6.6$ & $28.6 \pm 3.8$ \\
\hline & Abundance of ubiquitous spec & $161.3 \pm 16.4$ & $204.2 \pm 11.3$ & $241.4 \pm 21.1$ & $213.4 \pm 13.4$ & $182.6 \pm 35.5$ \\
\hline & Total number of species & $12.0 \pm 0.3$ & $13.0 \pm 0.7$ & $12.8 \pm 0.7$ & $12.6 \pm 1.1$ & $15.0 \pm 1.4$ \\
\hline & Number of Eumull species & $\mathbf{O c}$ & $0.8 \pm 0.4 b c$ & $1.4 \pm 0.2 b$ & $1.2 \pm 0.2 b$ & $2.4 \pm 0.5 a$ \\
\hline & Number of Dysmoder species & $5.2 \pm 0.4$ & $4.8 \pm 0.5$ & $4.8 \pm 0.5$ & $4.0 \pm 0.4$ & $4.6 \pm 0.6$ \\
\hline & Number of ubiquitous species & $9.6 \pm 0.5 a$ & $7.2 \pm 0.6 b$ & $6.6 \pm 0.5 b$ & $7.4 \pm 0.7 b$ & $8.0 \pm 0.5 a b$ \\
\hline & Water $\mathrm{pH}$ & $4.29 \pm 0.01 d$ & $4.33 \pm 0.02 c$ & $4.51 \pm 0.07 a b c$ & $4.46 \pm 0.02 b$ & $4.65 \pm 0.03 a$ \\
\hline
\end{tabular}




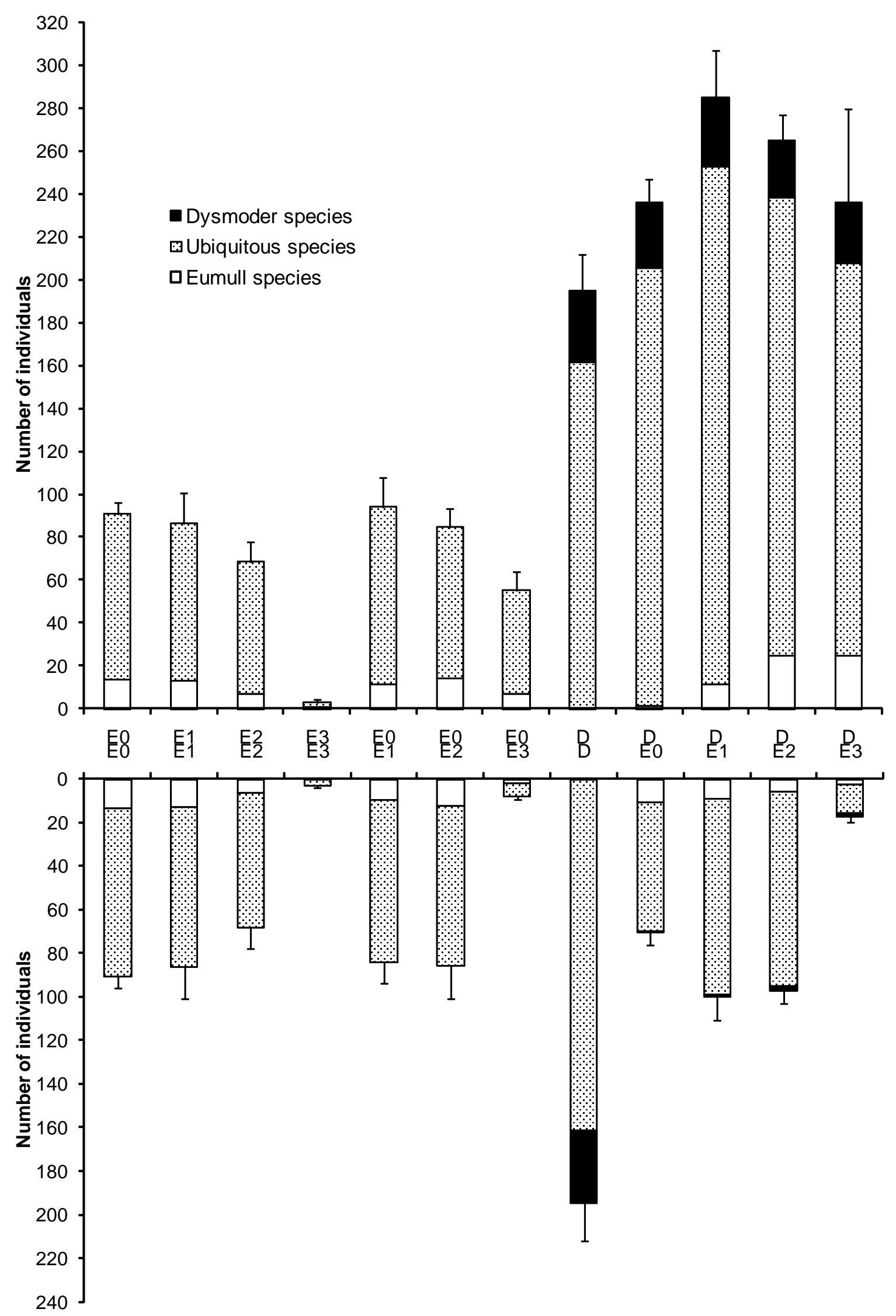




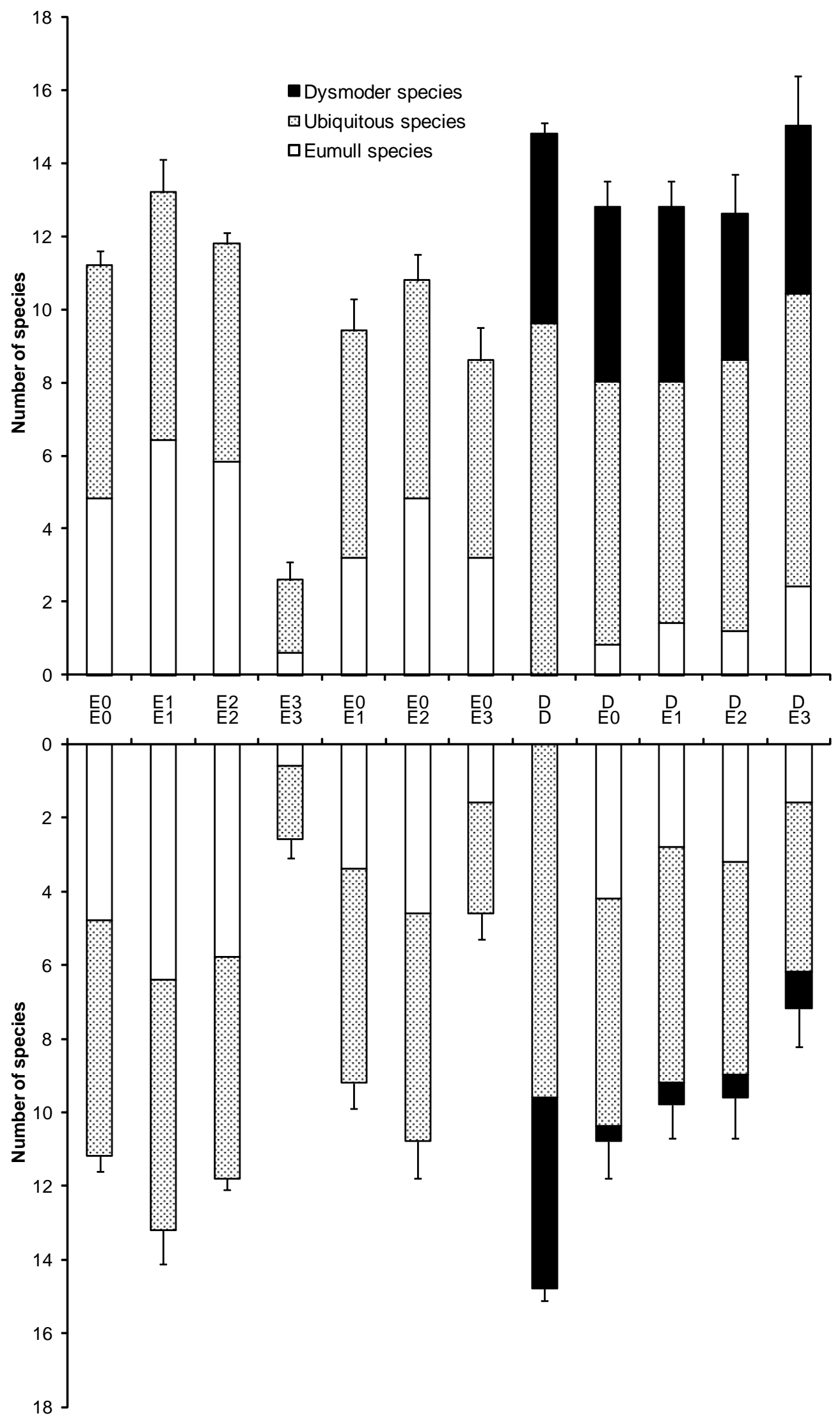

Fig. 2 


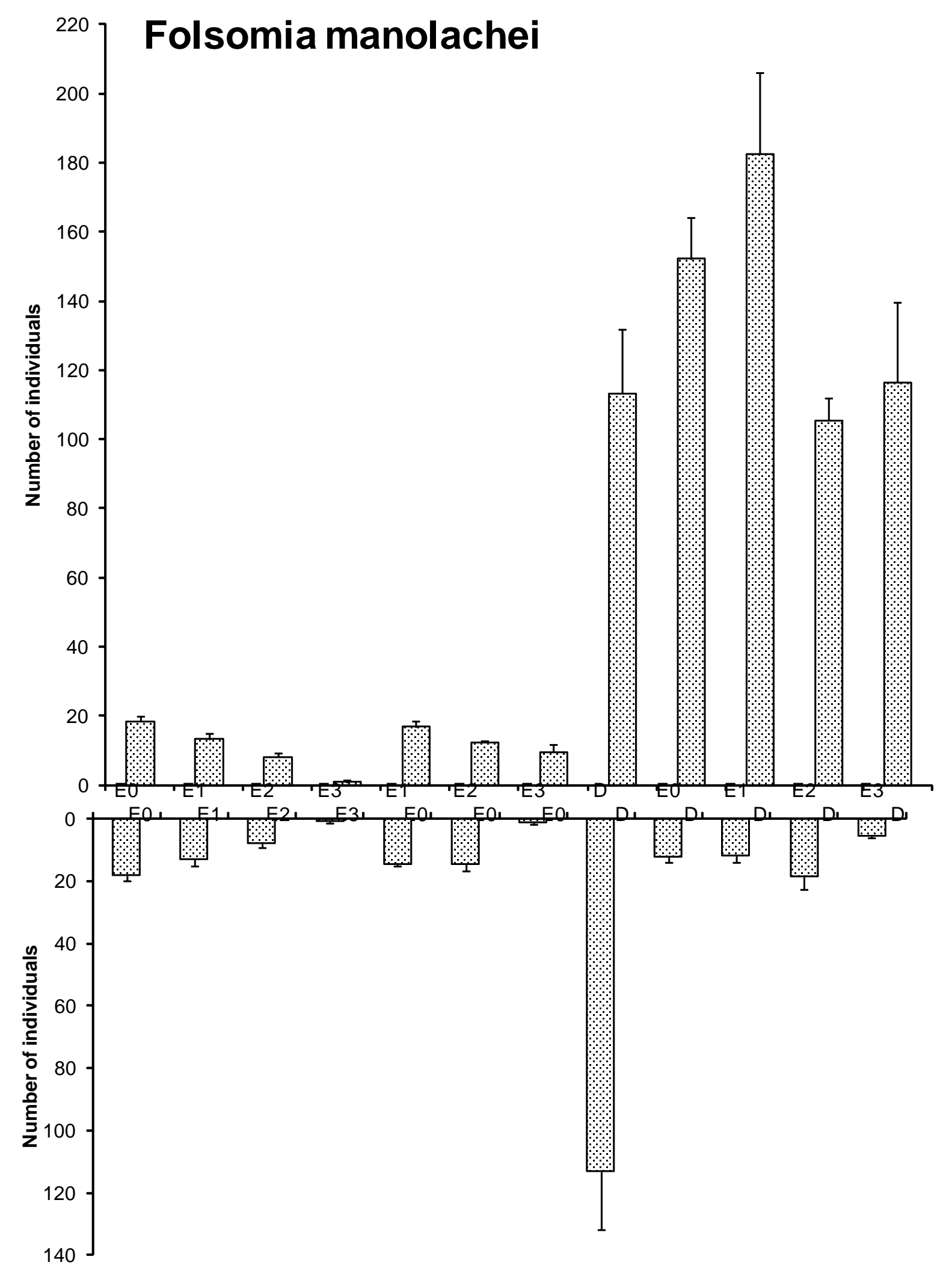

Fig. 3 


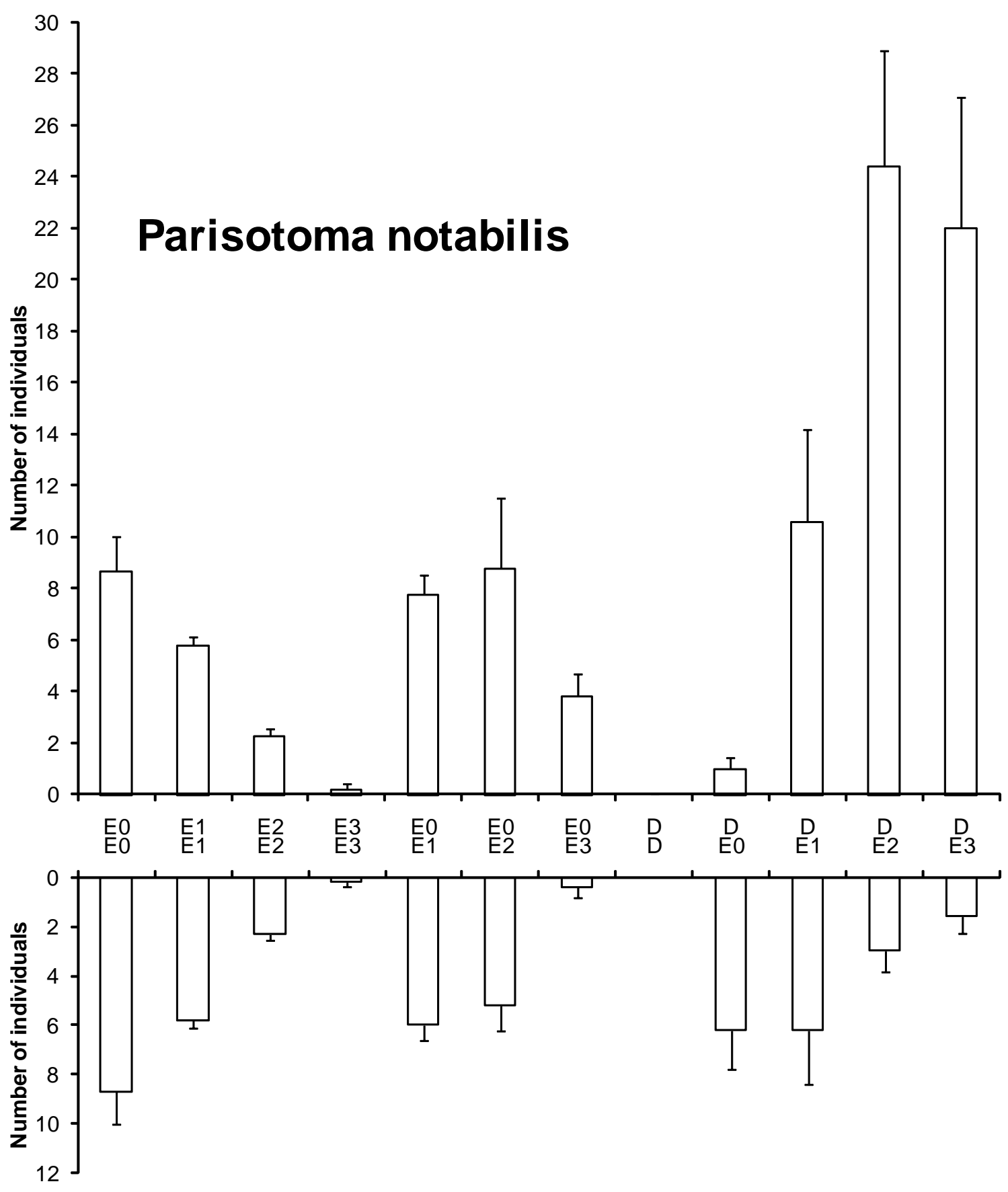

2 Fig. 4 